\title{
Sequential changes associated with the degeneration of preovulatory rat follicles
}

\author{
J. J. Peluso, R. W. Steger and E. S. E. Hafez \\ Reproductive Physiology Laboratories, C.S. Mott Center for Human Growth and \\ Development, Wayne State University, School of Medicine, Detroit, \\ Michigan 48201, U.S.A.
}

\begin{abstract}
Summary. In 26-day-old rats, follicles capable of ovulation were present $48 \mathrm{~h}$ after PMSG injection and they degenerated if not exposed to an ovulating dose of HCG. In such follicles ${ }^{125} \mathrm{I}$-labelled $\mathrm{LH}$ bound to the thecal and granulosa cells. By $60 \mathrm{~h}$ after PMSG, $\mathrm{LH}$ binding to the granulosa cells was reduced by $46 \%$, although these follicles retained their ability to ovulate. LH binding to the granulosa cells was lost in most follicles by $72 \mathrm{~h}$ and ovulation could not be induced. The thecal cells still possessed LH binding sites at $72 \mathrm{~h}$ after PMSG. HCG stimulation of these follicles resulted in the disruption of the granulosa and the invasion of blood cells into the antrum.
\end{abstract}

\section{Introduction}

Once an ovarian follicle begins to grow it is destined either to ovulate or to become atretic. In atretic follicles, mitotic activity ceases in the granulosa cells, pyknotic nuclei appear in the antrum, and the cumulus cells show necrotic changes (see Ingram, 1962). Lysosomes appear to be involved in follicular degeneration since two lysosomal enzymes, acid phosphatase and aminopeptidase, can be histochemically demonstrated only in the granulosa cells of atretic follicles (Lobel, Rosenbaum \& Deane, 1961). The granulosa cells of degenerating follicles in aged rats have reduced LH-binding capacity (Steger, Peluso, Huang, Hafez \& Meites, 1976). We therefore examined the relationship between follicular histology, serum LH and FSH levels, the presence of LH binding sites, the appearance of acid phosphatase activity within the granulosa cells and the ability of the follicle to ovulate in response to $\mathrm{HCG}$.

\section{Materials and Methods}

\section{Experiment I}

Twenty-five female Wistar rats, 24 days of age, were housed in a controlled environment $\left(24^{\circ} \mathrm{C}\right.$, $45 \%$ humidity and $14 \mathrm{~h}$ light $/ 24 \mathrm{~h}$ ). Twenty of these rats received 5 i.u. PMSG (i.p.) (Ayerst AY24,293-X-6) at $09.00 \mathrm{~h}$ on Day 24. The 5 remaining rats were not treated. The untreated rats were killed by decapitation at $09.00 \mathrm{~h}$ on Day 26 , and groups of 5 PMSG-treated rats were killed at 48, 60, 72 and $96 \mathrm{~h}$ after treatment. The ovaries were removed and one ovary from each rat was fixed in Bouin's fluid or placed in an embedding medium (OCT compound: Ames Co., Elkart, Indiana), frozen in a solid $\mathrm{CO}_{2}$-ethanol bath and stored at $-20^{\circ} \mathrm{C}$. Bouin-fixed ovaries were embedded in paraffin wax, sectioned and stained with haematoxylin and eosin.

Serum was prepared from each blood sample collected at autopsy and stored at $-20^{\circ} \mathrm{C}$ until assayed for LH and FSH content. LH and FSH were assayed using the radioimmunoassay kits provided by NIAMDD. The sensitivity and intra-assay variability were $5 \mathrm{ng} / \mathrm{ml}$ and $1.0 \%$ for LH and $8 \mathrm{ng} / \mathrm{ml}$ and $0.67 \%$ for FSH assay. Values were expressed as $\mathrm{ng} \mathrm{NIH-LH} \mathrm{or} \mathrm{FSH-RP1/ml} \mathrm{serum.}$

The LH binding sites were localized as described by Peluso, Steger \& Hafez (1976). Frozen sections were cut in a cryostat at $15 \mu \mathrm{m}$, then incubated for $1 \mathrm{~h}$ at $37^{\circ} \mathrm{C}$ with ${ }^{125} \mathrm{I}$-labelled $\mathrm{LH}\left(4.6 \times 10^{4}\right.$ $\mathrm{ct} / \mathrm{min} / 25 \mu \mathrm{l}$ ). After incubation, the sections were washed, air dried and dipped in NTB-3 emulsion. 
Most of the sections were lightly stained with haematoxylin and eosin to differentiate the theca and granulosa cell layers. For a semi-quantitative estimate of LH binding, grain counts were made on stained sections. The number of grains over a random $0.025 \mathrm{~mm}^{2}$ area of granulosa cells of the four largest follicles in each ovary was counted. Grain counts within the emulsion adjacent to ovarian sections were also made. Gonadotrophin binding was expressed as the difference between total grain counts over the granulosa and the grain counts within the emulsion. The ovaries were sectioned over a 5-day period with one ovary from each group sectioned on the same day.

Histochemical localization of acid phosphatase was carried out on frozen sections which were mounted on slides and air dried. The sections were covered with an incubation mixture (Pearse, 1968) consisting of a $3 \times 10^{-3}$ M-sodium $\alpha$-naphthyl phosphate, $1 \times 10^{-1}$ M-polyvinyl pyrrolidene and $3 \times 10^{-3} \mathrm{M}$-O-amino azotoluene, diazonium salt (Fast Garnet GBC Salt) in 0.1 M-veronal acetate buffer ( $\mathrm{pH} 5 \cdot 0$ ). The incubation medium was filtered through Whatman No. 40 filter paper before use. The sections were incubated at $37^{\circ} \mathrm{C}$ for $1 \mathrm{~h}$, washed in running tap water for 2 min and then mounted in glycerol-gelatin. Control incubations were performed in the absence of sodium $\alpha$-naphthyl phosphate. Acid phosphatase activity was revealed by the presence of a reddish brown deposit.

\section{Experiment II}

Forty-five female rats, 24 days of age, were given a priming i.p. injection of 5 i.u. PMSG. At 48, 60,72 or $96 \mathrm{~h}$ after the injection the rats were given an i.p. injection of 10 i.u. HCG (Ayerst) or $0.1 \mathrm{ml}$ saline. The rats were killed $24 \mathrm{~h}$ later. Oocytes were flushed from the oviducts with saline (see Table 2). The cumulus cells were dispersed with hyaluronidase and the oocytes were examined, counted and subsequently fixed, mounted on glass slides and stained with $2.5 \%$ lacmoid. The ovaries were also removed, fixed in Bouin's fluid, embedded in paraffin wax, sectioned and stained with haematoxylin and eosin.

Statistical evaluations were made with an analysis of variance or a $\chi^{2}$ test.

\section{Results}

\section{Histology and histochemistry}

The ovaries of untreated 26-day-old rats had preantral follicles and a few antral follicles. Most of the antral follicles were atretic as judged by the presence of pyknotic nuclei and acid phosphatase

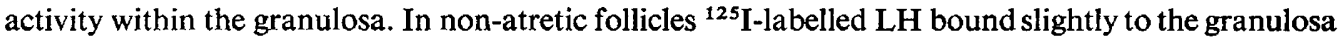
cells $\left(214 \pm 39\right.$ grains $\left./ 0 \cdot 1 \mathrm{~mm}^{2}\right)$. Binding was also observed over the theca and interstitium.

By $48 \mathrm{~h}$ after PMSG treatment, the ovaries contained many antral follicles. The largest follicles in each ovary were $500-600 \mu \mathrm{m}$ in diameter and were enclosed by a well defined theca which was slightly luteinized. These follicles possessed mitotic figures in the granulosa cells but not acid phosphatase activity. In addition, ${ }^{125} \mathrm{I}$-labelled $\mathrm{LH}$ bound to the granulosa $\left(617 \pm 66\right.$ grains $\left./ 0 \cdot 1 \mathrm{~mm}^{2}\right)$ and thecal cells (PI. 1, Fig. 7). The oocytes in these follicles were intact, did not have acid phosphatase activity and possessed distinct germinal vesicles and nucleoli. $\mathrm{LH}$ binding to the granulosa cells showed a $46 \%$ decrease by $60 \mathrm{~h}$ after PMSG treatment $\left(332 \pm 44\right.$ grains $\left./ 0.1 \mathrm{~mm}^{2}\right)(P<0.05)$. The frequency of mitotic figures in the granulosa cells had also decreased. Although the follicles were unaltered histologically (PI. 1, Fig. 1), acid phosphatase activity was noted in a few follicles, mainly in the granulosa cells and weakly over the cumulus oophorus and oocyte (Pl. 1, Fig. 2). In the largest follicles at $72 \mathrm{~h}$ after PMSG injection, the ${ }^{125} \mathrm{I}$-labelled $\mathrm{LH}$ bound to the theca and granulosa cells $\left(85 \pm 32\right.$ grains $\left./ 0 \cdot 1 \mathrm{~mm}^{2}\right)$, but there was no $\mathrm{LH}$ binding over the granulosa cells of $71 \%$ of these follicles (Pl. 1, Fig. 8). Although some cells were dividing, the granulosa cell layer was noticeably thinned, a few pyknotic nuclei were present in the antrum (Pl. 1, Fig. 3) and acid phosphatase activity was high (Pl. 1, Fig. 4). By $96 \mathrm{~h}$ after PMSG injection, the granulosa cells were not dividing and exhibited acid phosphatase activity (Pl. 1, Fig. 6). Many pyknotic nuclei were found within the antrum (Pl. 1, Fig. 5), and although the granulosa cells of most follicles did not bind $\mathrm{LH}$, the thecal cells still bound LH. 


\section{Serum $L H$ and FSH}

As shown in Table 1, serum LH levels were higher in the PMSG-treated rats than in the controls, but serum FSH levels were not altered.

Table 1. The effect of PMSG on mean \pm S.E.M. serum gonadotrophin concentrations (ng/ml) in immature rats

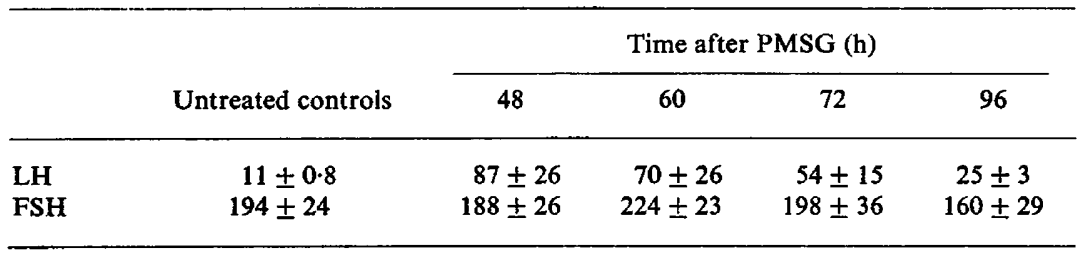

\section{Effect of $H C G$}

Ovulation occurred in response to HCG treatment in all groups (Table 2). The highest ovulation rate was at 48 and $60 \mathrm{~h}$ after the priming PMSG injection and the granulosa cells of all the ovulating follicles had luteinized. All the oocytes were surrounded by cumulus cells when flushed from the oviduct and had resumed meiosis; the chromosomes were arranged on the metaphase plate. At 72 and $96 \mathrm{~h}$ after PMSG, fewer follicles were capable of ovulating in response to HCG than at 48 and $60 \mathrm{~h}$ after PMSG $(P<0.05)$. In the follicles which did ovulate, the granulosa cells were luteinized; in the others, $500-700 \mu \mathrm{m}$ in diameter, the granulosa was not luteinized but was disrupted, meiosis had resumed, the basement membrane had broken down and red blood cells and leucocytes had invaded the antral cavity.

Table 2. The effect of $\mathrm{HCG}$ on ovulation in PMSG-primed immature rats

\begin{tabular}{|c|c|c|c|}
\hline \multirow[b]{2}{*}{$\begin{array}{l}\text { Time after } \\
\text { PMSG (h) }\end{array}$} & \multirow{2}{*}{$\frac{\text { Saline-treated rats }}{\begin{array}{c}\text { No. ovulating/ } \\
\text { no. treated }\end{array}}$} & \multicolumn{2}{|c|}{ HCG-treated rats } \\
\hline & & $\begin{array}{l}\text { No. ovulating/ } \\
\text { no. treated }\end{array}$ & $\begin{array}{l}\text { Ovulation rate* } \\
\text { (mean } \pm \text { S.E.M.) }\end{array}$ \\
\hline 48 & $0 / 5$ & $4 / 5$ & $18 \pm 6$ \\
\hline 60 & $0 / 3$ & $7 / 7$ & $20 \pm 3$ \\
\hline 72 & $0 / 5$ & $4 / 6$ & $2 \pm 1$ \\
\hline 96 & $0 / 5$ & $3 / 6$ & $7 \pm 1$ \\
\hline
\end{tabular}

*No. of ova/ovulating rat.

\section{Discussion}

By $48 \mathrm{~h}$ after PMSG treatment, the follicles of immature rats have acquired LH binding sites within the granulosa cells and the capacity to ovulate in response to HCG. The highest ovulation rate occurs when the interval between PMSG and HCG injections is $60 \mathrm{~h}$ (Rowlands, 1944, and present study) in spite of $\mathrm{LH}$ binding to the granulosa cells being reduced by $46 \%$. If the interval between PMSG and HCG is extended to 72 or $96 \mathrm{~h}$, most of the follicles have lost their LH binding sites and the ability to ovulate and luteinize in response to HCG. These follicles exhibit acid phosphatase activity within the granulosa cells (an early indicator of atresia) and appear to be in Stage I of atresia (see Byskov, 1974). When such follicles are stimulated by HCG treatment, the changes (see 'Results') are characteristic of those of Stage II atresia. This effect of HCG is presumably mediated through the thecal cells which still possess $\mathrm{LH}$ binding sites.

Gonadotrophins can increase follicular growth and also the rate of atresia (Harman, Louvet \& Ross, 1975). Low doses of HCG induce follicular atresia by stimulating androgen synthesis within the 
interstitium (Louvet, Harman, Schreiber \& Ross, 1975). In addition, LH and FSH trigger the release of ovarian lysosomal enzymes, including acid phosphatase (Dimino \& Reece, 1974). Whether the small LH surge found in the present study is sufficient to affect the process of atresia is uncertain.

We thank Mr Phil Sherman and Mr Angelo Perri for their excellent technical assistance, and NIAMDD for providing the radioimmunoassay kits for LH and FSH. The work was supported in part by Ford Foundation Grant 710-0287A and NIH Grant RR-05384.

\section{References}

Byskov, A.G.S. (1974) Cell kinetic studies of follicular atresia in the mouse ovary. J. Reprod. Fert. 37, 277-285.

Dimino, M.J. \& ReEce R.P. (1973) Effect of gonadotropic hormones on rat ovarian lysosomes. Biol. Reprod. 8, 523-530.

HaRman, S.M., Louvet, J.-P. \& Ross, G.T. (1975) Interaction of estrogen and gonadotropins on follicular atresia. Endocrinology 96, 1145-1152.

INGRAM, D.L. (1962) Atresia. In The Ovary, Vol. I, pp. 247-273. Ed. S. Zuckerman. Academic Press, New York.

Lobel, B.L., Rosembaum, R.M. \& Deane, H.W. (1961) Enzymic correlates of physiological regression of follicles and corpora lutea in ovaries of normal rats. Endocrinology 68, 232-247.
Louvet, J.-P., Harman, S.M., Schreiber, J.R. \& Ross, G.T. (1975) Evidence for a role of androgens in follicular maturation. Endocrinology 97, 366-372.

Pearse, A.G.E. (1968) Histochemistry, 3rd edn, Vol. 1, p. 998 . Little Brown, Boston.

Peluso, J.J., Steger, R.W. \& Hafez, E.S.E. (1976) Development of gonadotrophin-binding sites in the immature rat ovary. J. Reprod. Fert. 47, 55-58.

RoWLANDS, I.W. (1944) The production of ovulation in the immature rat. J. Endocr. 3, 384-391.

Steger, R.W., Peluso, J.J., Huang, H., Hafez, E.S.E. \& MEITES, J. (1976) Gonadotrophin-binding sites in the ovary of aged rats. $J$. Reprod. Fert. 48, 205-207.

Received 24 June 1976

\section{EXPLANATION OF PLATE 1}

Figs 1 and 2. Follicles $60 \mathrm{~h}$ after PMSG treatment $(\times 150)$. These follicles show some thinning of the granulosa but the oocyte possesses an intact germinal vesicle (Fig. 1). Acid phosphatase activity is present in the granulosa cells but is very weak in the cumulus oophorus and oocyte (Fig. 2).

Figs 3 and 4. Follicles $72 \mathrm{~h}$ after PMSG $(\times 150)$. In these follicles the granulosa is very thin and a few pyknotic nuclei can be seen in the antrum (Fig. 3). Acid phosphatase activity is high in the granulosa cells, cumulus oophorus and oocyte (Fig. 4).

Figs 5 and 6. Follicles $96 \mathrm{~h}$ after PMSG ( $\times 150$ ). Many pyknotic nuclei are found in the antra of these follicles, but the oocyte is still intact with an intact germinal vesicle. No leucocytes or red blood cells are observed within the antrum (Fig. 5) and acid phosphatase activity is still very high (Fig. 6).

Fig. 7. Autoradiograph demonstrating that ${ }^{125}$ I-labelled $\mathrm{LH}$ binds to the thecal and granulosa cells $48 \mathrm{~h}$ after PMSG treatment. $\times 150$.

Fig. 8. Autoradiograph of a follicle $72 \mathrm{~h}$ after PMSG showing that the ${ }^{125}$ I-labelled LH was bound only to the thecal cells. $\times 150$. 


\section{PLATE}
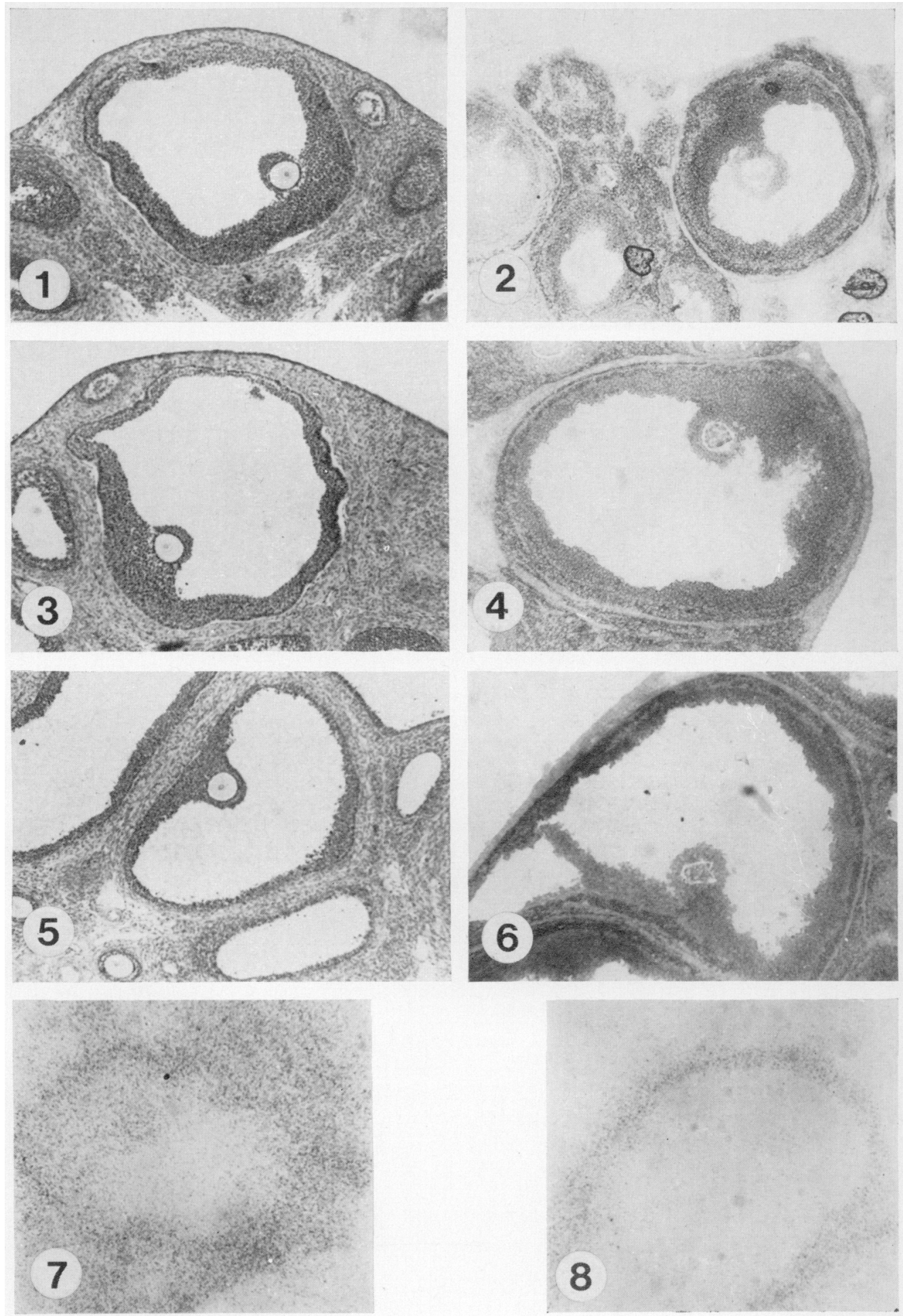